\title{
ELABORATION ON CONCEPTS OF RESTITUTION AND COMPENSATION AS A FORM OF LIABILITY IN PRIVATE LAW
}

\author{
${ }^{1}$ Faizal Kurniawan \\ Faculty of Law, Airlangga University \\ Surabaya, Indonesia \\ faizal_law@yahoo.co.id \\ ${ }^{2}$ Erni Agustin \\ Faculty of Law, Airlangga University \\ Surabaya, Indonesia \\ erni@fh.unair.ac.id
}

\author{
${ }^{3}$ Rizky Amalia \\ Faculty of Law, Airlangga University \\ Surabaya, Indonesia \\ Rizkyamalia07@gmail.com
}

\begin{abstract}
Recent development to claim damages on the basis of either default or unlawful acts would not provide saticfactory grounds to the question of justice. There will be a situation in which that no one shall be unjustly enriched at the expense of another which all outside the scope of contract and unlawful acts (or torts). This has led to the existence of an independent legal doctrine known as unjust enrichment. It is among the most debated private law subjects today in asking for justice. Corrective justice brings to the remedial relation between the plaintiff and the defendant; it is solely concerned with the norm of justice that provides reasons to restitution. Corrective justice properly evaluates the structure of unjustness to the both sides, the plaintiff and the defendant. It gives effect to restitutionary proprietary interests rather than compensatiton. This article elaborates the law of unjust enrichment as ground for restitution in conjunction with the corrective justice. Furthermore, this article focuses on the theoritical foundation of corrective justice to meet the unjustified enrichment criteria.
\end{abstract}

Keywords-Corrective Justice; Unjustified Enrichment; Unjustness; Loss.

\section{INTRODUCTION}

The debates on Law of Obligation, as part of the Civil Code1 within the last few decades focused on the efforts to find a new basis for a method to restitute or to compensate losses that arise from situation without any contractual relationship between the parties involved.2 Until now, the demand for restitution or compensation in the Civil Code, including in Indonesia, are dominated by two basic lawsuits: lawsuit based on contractual relations and lawsuit based on torts or unlawful acts. 3 However, most legal experts in the world see that these two basic lawsuits and their variations have not been able to accommodate the world's fast progress and evolution of law. In certain circumstances, where there is no contractual relationship between the parties involved and no mistakes found from the receiving party in such circumstances, a lawsuit based on contractual relations or based on unlawful conduct cannot be filed4. The most obvious and often used example to describe this situation is the occurrence of a payment error.

A customer who incorrectly paid his/her bills twice should be entitled to a reimbursement for the second payment. However, in such circumstances, the second payment made by the customer was exercised in the absence of a contractual relationship with the seller, nor did the seller make a mistake causing the customer to make 
the second payment. In other words, the customer is unable to file a lawsuit on a contractual basis or unlawful act basis. This is clearly against the basic principles of justice as one of the main goals of law, between the objective of legal certainty and the objective of legal benefit. 6 The demand for a new basis for filing a lawsuit for the purpose of legal justice has given birth a concept known as unjust enrichment.7 In general, the Unjust Enrichment Doctrine is defined as below:

General principle that one person should not be permitted unjustly to enrich himself at expense of another but should be required to make restitution of or property or benefits received, retained or appropriated, where it is just and equitable that such restitution be made, and where such action involves no violation or frustration of law or opposition to public policy, either directly or indirectly.

Several literature and essays state that the philosophical basis for the application of unjust enrichment doctrine is to achieve corrective justice.9 The concept of corrective justice itself is altered from the thought of Aristotle as one of the philosophers who initiated the concept of justice. Aristotle argued that accountability is a legal response to injustice. 10 Furthermore, Aristotle stated that the concept of justice can be divided into two types, namely distributive justice and corrective justice.11 Distributive justice is defined as, "That which is manifested in distribution of the honor or the other things that fall in the constitution, which may be allotted among its members in equal or in unequal shares". Meanwhile corrective justice or also known as restorative form of justice is defined as an action to balance something that is unbalanced due to an injustice.12

Initially, corrective justice is used only as a basis to determine justice and accountability for unlawful acts13, whereas distributive justice is used as a basis for fair sharing of rights and obligations between the parties involved in a contractual relationship. 14 This is due to the nature of corrective justice that seeks to eliminate the gain that cannot be justified which may cause losses on the other side, so that corrective justice attempts to provide restitution 15 to the injured party or in other words to return the injured party to its original state before the loss took place.16 Meanwhile distributive justice emphasizes on the efforts to give or divide the rights and obligations of the parties proportionately indicating that the parties are involved in a contractual relationship which serves as a basis to share the rights and obligations concerned in proportion.17 The consequence of this conceptualization between distributive justice and corrective justice has been expressed by Aristotle where distributive justice cannot be applied as the basis of the occurrence of one's liability to another,18 which can be more appropriately served by corrective justice.19

The presence of unjust enrichment doctrine in Civil Law are well-known in many countries, both of which apply common law and civil law system. However, the scope and setting of unjust enrichment vary in each countries. The Netherlands has enacted the concept of unjust enrichment in Article 212 Book 6 NBW which principally stipulates that, "A person who has been unjustifiably enriched at the expense of another is obliged, insofar as reasonable, to make good the other's loss up to the amount of his enrichment." 20 This provision indicates that the criterion of unjust enrichment in the Netherlands is very wide. As far as the return is "reasonable" and can be calculated nominally, the benefited party benefitting an unjust wealth or property shall return it to the rightful party. Whereas in the United States, based on Restatement of the Law (Third) Restitution and Unjust Enrichment, the criteria of unjust enrichment are as follows: a. A benefit which has been unjustly received (the "enrichment"); b. A loss or detriment suffered, usually by the plaintiff; c. A rule of law which deems the enrichment (or the retention of it) "unjust"; $d$. A prima facie duty to make restitution; e. Absence of a valid legal basis for the payment or transaction (including voluntariness or election); and f. Absence of a defense.21

In Indonesia, the concept of unjust enrichment in Indonesia is more familiar and widely discussed as a concept in the Criminal Law, especially the Law of Corruption, which is adapted from the provisions of Article 20 of the United Nations Convention Against Corruption (UNCAC) in 2003 which has been ratified by Indonesia through Law no. 7/2006 on Ratification of United Nations Convention Against Corruption. The concept of unjust enrichment in Article 20 of UNCAC is termed as illicit enrichment which can be freely interpreted as a wealth of unknown origin or unreasonable wealth.22 Article 20 of UNCAC states that, 
Subject to its constitution and the fundamental principles of its legal system, each State Party shall consider adopting such legislative and other measures as may be necessary to establish as a criminal offence, when committed intentionally, illicit enrichment, that is, a significant increase in the assets of public official that he or she cannot reasonably explain in relation to his or her lawful income. 23

The implementation of the concept of unjust enrichment in Indonesia is clearly against the initial concept of unjust enrichment which was born from Civil Law, especially when it comes to Property Law. Under such circumstances, Indonesia should regulate unjust enrichment as the basis of civil accountability (and/or liability) as a response to the public unrest and general demand for justice, especially for the existing business relations in the community, given that the concept of accountability known in Indonesia up to this point, which are the contractual basis accountability and unlawful acts based accountability, are deemed no longer compatible with the value of justice and the community development. For this reason, this paper seeks to elaborate the concept of unjust enrichment in its application as the basis of demands for compensation or restitution in Indonesia based on the corrective justice doctrine, with the following focus of discussion: 1) the criteria of profit and loss in unjust enrichment; and 2) the definition of corrective justice as the philosophical foundation to determine the criteria of unjust enrichment.

\section{THE CRITERIA OF PROFIT AND LOSS IN UNJUST ENRICHMENT}

The concept of unjust enrichment is the manifestation a functioning law in realizing a fair civil relationship, especially in business activities. The concept of unjust enrichment itself is based on the principle of "one would not be allowed to unjustly enrich himself at the expense of another" as presented by Keener in an article published in the Harvard Law Review 1887 which began to be developed in the period of Quintuis Mucius Scaevola24 that rooted back from the Greek philosophy "The Moral to Nichomaquean".25 The principle is in line with the principle of suum cuique tribune or giving to everyone what is their right. The principle of "one shall not be unjustly enrich himself at the expense of another" has been basically known since Justinian's Digest (6th century AD) which was marked in two texts for Roman scholar Pomponius. 26

In the last few decades, this principle has developed into a basis for claiming indemnification into the principle of "A person who has been unjustly enriched at the expense of another is required to make restitution to the other" which in the United States has been formulated in the Restatement of the Law (Third) Restitution and Unjust Enrichment which altered the Restatement of Restitution (1937).27 This basic accountability principle was only known in the common law system from the last few decades but has long been embraced in the civil law system. 28 This relatively new unjust enrichment doctrine became the most dynamic basis for accountability in the Civil Code since the mid-1980s and now has become a vital doctrine in the Civil Code. 29

In the Netherlands, the unjust enrichment doctrine startedin 1992 by creating a provision for unjust enrichment in Article 6: 212 of the NBW.30 In Indonesia, in some literatures it is stated that a claim on the basis of unjust enrichment can refer to the provisions of Article 1359 paragraph (1) BW regarding unpaid payment, stating that "each payments shall refer to the existence of a debt; and what has been paid without liability can be asked to be returned".31 However, the concept of unjust enrichment can not necessarily be equalized with the concept of payment without liability as referred to in Article 1359 paragraph (1) of BW.

In the case of Everhart v. Miles, 47 Md.App 131, 136,422 A $2 d 28$, it is affirmed that within the judge's judgment that there are 3 (three) elements to determine the occurrence of unjust enrichment, i.e. a) there is a benefit or advantage provided or made by the plaintiff to the defendant; $b$ ) these benefits are valuable or understood by the defendant; c) the action of accepting or withholding the benefits without payment by the defendant is considered improper.32 Based on Restatement of the Law (Third) Restitution and Unjust Enrichment, the criteria of unjust enrichment are "a) A benefit which has been unjustly received (the "enrichment"); b) A loss or detriment suffered, usually by the plaintiff; c) A rule of law which deems the enrichment (or the retention of it) "unjust"; d) A prima facie duty to make restitution; e) Absence of a valid legal basis for the payment or transaction 
(including voluntariness or election); f) Absence of a Defense."

Under the English Law, to declare an act "unjust", it shall satisfy one of the following factors "a) Mistake of fact; b) Mistake of law; c) Duress; d) Undue influence; e) Total failure of consideration; $f$ ) Miscellaneous policy-based unjust factors; g) Ignorance/powerlessness; h) Unconscionability; i) Partial failure of consideration; j) Absence of consideration."33 Based on these criteria, it is important to establish the right scope or jurisdiction of unjust enrichment. If the scope is too broad, the parties will not be able to recognize the boundaries, however if the scope is too narrow, there is a greater chance for someone to lose his or her rights which will obviously lead to injustice. 34

To address this issue, the common law system imposes restrictions on the return or restitution of payment errors only if the payment or transfer is not intended by the transferor. So the transferor party must be able to state that he/she does not intend to send the payment or the property to the receiving party. In relation to the case of a double payment of a bill, the consumer must be able to state that he or she does not intend to pay the bill for a second time. 35

It is a different case between a home owner and a house decorator, where the owner of the house is unlikely to state that he/she does not intend to pay the house decorator after having decorated the house. Both of examples show firm differences to apply the unjust enrichment doctrine. In practice, however, it may be difficult to distinguish which case a payment belongs to.36 To overcome this, the common law system establishes a boundary to differentiate when a payment can be withdrawn and when the payment is binding so that no withdrawal or refund can be made.

The first restrictive mechanism is a vitiated intention which may become the basis for the transferor to argue that there is no intention nor action of such payments to the receiving party, in other words the intention is defective or incorrect. In addition, in an attempt to limit the number of proposed restitution requests, the common law system also distinguishes 'causal mistakes' in which the paying party commits a misconduct or the intention is defective from the paying party, and 'causal mispredictions' in which the paying party commits errors in calculating business risks. In the case of 'causal misprediction' the restitution claim cannot be justified. 37

Then, the second mechanism applied to underlie a restitution claim is 'failure of basis' or 'failure of consideration'. The 'failure of consideration' in the concept of unjust enrichment implies a failure of implementation, which does not necessarily mean that there is a contractual relationship indicating the presence of a contractual obligation to be executed. The 'failure of consideration' within the concept of unjust enrichment is very unique and different from the concept of contracting law which defines 'failure of consideration' as 'there is no promised counterperformance, so there is no binding contract in the 'failure of consideration'. For example, a homeowner pays a house decorator who does not perform his/her duties, which in this case the payment from the home owner can be refunded because the home owner intends to pay the decorator within a clear legal relationship, after which the contract has been agreed but not executed. In other words, there is no vitiated intention in the paying party. In such circumstances, the paying party may only demand to have the contract with the decorator be terminated. Such claim may be made on the basis of default or on the basis of 'reliance damages' of the made payments through unjust enrichment.38

Both restrictions are considered by modern jurists to be unfounded and no longer appropriate to apply.39 Modern jurists then reformulated these two restrictions from 'vitiated intention' to 'unintended transfer' because legally the intention of the paying party is to engage in contractual relations and make legally binding legal payments, however the intention of making the payments as the contract's implementation is defective.40 The second limitation is also altered from total failure consideration to unintended gift, where the payment is intended by the paying party as a commercial engagement, not as a reward. In other words the paying party does not intend to give a gift to the receiving party. 41

In addition, modern jurists also declare that if a contract is void due to breach of contract or default of obligation by one of the parties, then the party who has not obtained the consideration as stated in the contract may file the claim on the basis of unjust enrichment. Such claims cannot be filed on the basis of material claims due to its in personam status and 
not in rem.42 This means that the plaintiff requests for the realization of the consideration in the contract by the defendants, and not the material restitution of the plaintiff. 43 However, in Indonesia, such lawsuits that distinguish between an in personam lawsuit and in rem law suit are still not fully understood by academics and law practitioners.

Based on the above explanation it can be concluded that the concept of unjust enrichment is starting to become popular as one of the forms of engagement which creates rights and obligations, in addition to the commitments arising from an agreement and from a law that has been widely accepted in various countries. As a basis of an engagement, the unjust enrichment doctrine indirectly also creates rights and obligations among the parties to the gain and the loss that occur from the state of unjust enrichment. In this case, Kantian tries to interpret Aristotle's original idea of the relationship between rights and obligations by stating that the relationship between gain and loss refers to the relationship between rights and obligations. Aristotle observes that,

"Gain" is what it is generally called in such cases, even though in certain cases it is not the appropriate term, for instance, for one who struck another - and "loss" for the one who suffered-but when the suffering is measured, it is called a loss for one party and a gain for the other.44

From Aristotle's observations we can also observe that the position of gain and loss is mutual reciprocity, where if one party gains, the other will receive losses. In such circumstances, Aristotle adds that corrective justice seeks equality between the parties, so that if an event disturbs equality between the parties and causes unfairness, then corrective justice seeks to make the gaining party to correct the losses by returning the gain to the losing party. By doing at one time the action eliminates both gain and loss, and the parties return on the same state of equality. 45

Aristotle considers that it is the duty of a judge to be able to restore justice in the form of equality of gain and loss among the parties.46 Therefore, between the occurring gain and loss there must also present a relationship that affect each other. This restricts the claim of restitution to a person, in the sense that a person cannot demand the return of payment to any other person at will, and can only be claimed to the party who actually benefits from the loss he/she suffered. This distinguishes between corrective justice and distributive justice, where distributive justice involves various gain and loss in accordance with several criteria. Rather than connecting one party to another as the gaining party and the losing party, distributive justice actually divides the gain or the loss to all parties involved. In addition, distributive justice also does not limit itself to a two-party relationship, and may involve more than two parties at the same time.47

The concept of gain and loss in unjust enrichment cannot be equalized with the gain and loss in an engagement stemming from contractual relationship or unlawful action. In Indonesia, losses in Civil Law may originate from a breach of contract or unlawful action. Based on the provisions of Article 1246 BW, it can be seen that the elements of loss in a default or breach of contract consist of cost, loss and interest.48 Losses in unlawful action are not clearly stipulated, but implicitly mentioned in Article 1371 paragraph (2) and Article 1372 paragraph (2) of BW indicating that losses due to unlawful acts are only in the form of schaden or losses. In addition, losses in unlawful acts include material losses and immaterial losses which value will be assessed with money, while losses in breach of contract or default are in the form of material losses.49

In the concept of corrective justice, the concept of loss is the other side of gain that must be reequalized to bring about justice for all parties involved, in accordance with the norms governing the activities that occur between the parties.50 Losses arising from an unlawful act, for example $A$ hurt $B$, then the suffering of $B$ can only be regarded as a loss if the suffering can be measured and at that time losses and gains befalls for the other party. 51

\section{THE CONCEPT OF CORRECTIVE JUSTICE AS A PHILOSOPHICAL FOUNDATION TO DETERMINE THE CRITERIA OF UNJUST ENRICHMENT}

Justice has always been an integral part of the law. Law without justice cannot be called law, because justice is one of the main objectives of the law.52 Similarly, when discussing the doctrine of unjust enrichment, the term "unjust" shows that this 
doctrine has particularity in relation to justice, since the concept of "unjust" have to clearly describe justice itself.53 In relation to the conception of "unjust", Peter Birks states that "... that "unjust" can never be made to draw on an unknowable justice in the sky."54 Based on this opinion of Peter Birks, the discussion on the concept of injustice cannot be separated by the discussion of the concept of justice itself. The question on the concept of justice is a basic question that has always been one of the main topics of conversation of all time, even Robert Reiner in his article "Justice" has termed the debate over justice as an 'essentially contested concept'.55

Since the days of Roman and Greek, there have been many philosophers brought forward their on justice. Among them are Plato who describes justice as part of virtue; 56 Aristotle, who portrays justice as the ultimate virtue by assuming that the same things shall be treated equally, while the different things shall be receive unequal treatment proportionately, 57 which later this view from Aristotle is shared by L. J. van Aperdoorn58; Ulpianus who illustrates justice as a constant and steady desire to give to everyone what is their due;59 Justianus in Corpus luris Civilis who states that the basic rules of the law relates to a life worth living, i.e. not harming others and giving someone his/her right;60 Thomas Aquinas who carries the concept of distributive justice, i.e. giving or distributing to someone in proportion to what they should receive; 61 and other philosophers who express their opinions on the concept of justice.

In addition, there are some philosophers who specifically articulate their thoughts on justice within the Civil Code, among others John Rawls who argues that a justice is born as a justice agreed by the community.62 Furthermore, Rawls emphasizes on justice based on the rationality of "self-interest" which is a collective binding agreement formed by the society.63 In essence, Rawls's principle of justice is not about justice in general, but rather emphasizes justice as a frame or a tool for individuals with different interests to achieve the right objective and the right value, which then the right value will be agreed as the value of truth in society. Rawls's theory is often referred to as "social justice". 64

The problematic question that emerges from this concept of justice according to Rawls is the abstraction of justice in general to the various legal relationships born in society, such as contractual relationships, accountability of teacher/employer which are based on mere assumptions on "the basic structure of society" or the values that have been agreed upon in society. To evaluate disputes between multiple parties, the institutional values, which have been accepted as the consensus, are used, for example: Company Regulations.65 This constraint shall be encountered in constructing justice based on "the basic structure of justice" according to Rawls.

On the other hand, Hart positions himself in "legal positivism" which is certainly contrary to the conception of natural law theory. He claims that, (1) a legally recognized set of rules is the law; and (2) the public must accept and comply with the recognized rules as "primary rules". 66 Every enacted rule is valid and applicable. Enacted and enforced rules remains despite being never accepted or applied by anyone. Hart further states that the validity of a rule must be distinguished from the effectiveness of the rule. The positivists emphasize the recognition of a rule rather than its effectiveness. Ineffective rules are still valid and applicable as long as they are not revoked by the sovereign authority. Hart's opinion is in line with the view of John Austin who states that the rule is the authority of the ruler if the ruler has a mandate from the community. So the justice referred to in the view of "legal positivism" is the justice contained in the legal provisions that have been instituted by the competent authorities.

The philosophers' view on the theory of justice as described above has not been able to respond appropriately the definition of "unjust" within the concept of "unjust enrichment". As it is known, the most fundamental thing in the rationale of unjust enrichment doctrine is the absence of unjustness. One way of view to assess the increase if a gain that a person obtains is unjust or not is through corrective justice. Corrective justice rectifies injustice between the engaged parties. The injustice committed by the defendant and the injustice suffered by the plaintiff is a reciprocal unity and is mutatis mutandis against the burden of accountability. Therefore, to understand injustice, it is necessary to elaborate in advance the structure of injustice. The structure of injustice departs from claim on the rights and the execution of obligations.67 In principle, corrective justice can be enforced if the structure of injustice is in line with the correlative structure of accountability. 
The correlative structure on injustice is intended to achieve coherence and fairness. The correlative structure of justice put all parties, either the plaintiff or the defendant, in an equally unfair state, so that each party is liable to a burden of accountability. The correlative structure is based on the principle of wholeness (or thematicity) 68. Based on this principle, each accountability is always correlated with the character of the engagement arising from the parties, such as obligations from a contractual relation and unlawful act from negligence. In creating a correlative structure in unity, it is articulated in each legal concept underlying all legal relations between the parties. The concept then becomes the basis to determine the size of a single injustice that applies to both parties that are bound. 69

As a reaffirmation, obligation is born from a contract and from an unlawful act. These two concepts carry different consequences of accountability. To measure injustices in a contractual relationships one can be identify the principle of good faith underlying the relationship of the contracting parties. Normatively, good faith is one of the essential principles in evaluating a contractual justice created by the parties. The size of contractual justice is put in good faith and good consciences both in the stage of contract creation until the execution of the contract, and even the actualization of the principle of good faith is stated implicitly in the clauses of the contract.70 Andrew Wallis adds that good faith requires all parties to act reasonably in achieving the contractual justice.71

On the other side, in case the obligation as a result of an unlawful acts, the conceptual approach used is the violation of laws and regulations as well as the norm of propriety and prudence. 72 Within this concept of unlawful acts, one should find the point of error or negligence with the losses suffered as the result of a wrongful/unlawful action. In creating a collective structure of an injustice, a form of injustice which can be applied to both parties, both to the plaintiff and the defendant, should be formulated. Therefore the risk of loss borne by the plaintiff is indeed a logical consequence of an error or negligence (wrong done/wrong suffered). Whereas in the case of unjust enrichment, the concept of unjust enrichment does not need to prove whether there is a good faith and honesty in the contract or to prove the existence or absence of mistakes or negligence, as an unjust enrichment lawsuit is not based on a contractual relationship or unlawful act. The unjust enrichment concept emphasizes the addition of "unjustly gained" wealth or property, causing losses on the one hand and gains on the other.73

As previously described, that any injustice or inappropriateness in obtaining wealth or benefit of a legal action so as to cause loss on one hand and profit on the other, cannot be necessarily classified as "unjust", however every gained benefit must meet the elements of "unjust enrichment". Therefore it is important to determine the criteria of unjust enrichment as the basis for implementing the unjust enrichment doctrine itself. One way to define unjust enrichment criteria is to base on the corrective justice as proposed by Aristotle. 74

Aristotle's view of justice begins with the idea of goodness as the goal of the law of nature, therefore justice is based on the laws of nature, wherever unchangeable and the same, whereas the justice made by man differs in different place because it depends on the constitution where the law is made.75 Aristotle's view provides an overview of the law in which the higher law is defined as a person who never changes, on the contrary, positive law decisions, constantly changes. In analyzing justice, Aristotle distinguished justice in general and justice in particular sense. In general, there are two concepts of justice: lawfulness and equality. As for justice in particular sense, which consists of equality, there are two kinds of justice: distributive justice and corrective justice.

Distributive justice is exercised in the distribution of honor, wealth, and the other divisible assets of the community which may be allotted among its members in equal or unequal shares by the legislator.76

Corrective justice is that which supplies a corrective principle in private transactions... those which are voluntary and those which are settling disputes and inflicting punishments upon delinquents. 77

Based on these definitions, corrective justice is directed primarily to the technical principles that govern the administration of law, where a general measure should be present to improve the consequences of action regardless of the person 
concerned. Therefore, these measures must be evaluated by an objective measure.78

In addition, Aristotle also explains that corrective justice is equal, but equality in this case is not based on geometry but based on arithmetic proportions.

It is not equality of two ratios. It is equality of two things, especially of two losses or two gains. A typical example is barter, which may stand for any voluntary transaction. Corrective justice requires that the service and counter service constituting the barter should be equal. The loss of one party by doing a service to the other party ("doing a service" comprising also making a gift to other party) shall be equal to the loss of the latter by doing a return service ("doing a return service" comprising also giving a return gift); and vice versa: the gain of one party in receiving service from the other should be equal to gain of the latter by receiving a return service from the former.79

Corrective justice is the theoretical notion that sets out what it means for private law to be fair and coherent. 80

In a relationship that is not based on the voluntary, corrective justice applies to determine the middle point as a proportion of the gain and the loss. 81

In practice, the general criteria used by many countries to determine whether a person has enriched themselves unjustly or whether there is an unjust enrichment, are the three elements stated in the Verdict in Everhart vs. Miles, 47 Md. App 131, 136,422 A 2D, which are 1) there is a benefit which the plaintiff has given or brought to the defendant; 2) these benefits are valuable or understood by the defendant or in other words have economic value; and 3) the defendant accepting or withholding the benefit is considered inappropriate (unjust) if not accompanied by a payment for the benefit.

These three criteria of unjust enrichment are the result of the application of Aristotle's classical theory of corrective justice which seeks to eliminate errors on unreasonably obtained gains on one party and the loss suffered on the other party.82 Aristotle also put forward the concept of liability which is a form of response to the unfair benefit received by the defendant against the losses suffered by the plaintiff, 83 where in the event of an unjust enrichment then comes the obligation of a party receiving the benefit to conduct a restitution to the person suffering the loss. 84

What distinguishes the application of unjust enrichment between different countries lies in the scope of action deemed inappropriate (unjust) as one of the criteria of unjust enrichment. Under the English Law, to declare a presence of unjust enrichment, it must meet one of the following factors: a) Mistake of fact; b) Mistake of law; c) Duress; d) Undue influence; e) Total failure of consideration; f) Miscellaneous policy-based unjust factors; g) Ignorance/powerlessness; h) Unconscionability; i) Partial failure of consideration; or j) Absence of consideration.

Concerning the concept of equity as which is acontrario to the concept of unjust, Aristotle argues that equity is complementary to the enforcement of justice and serves as the guardian of the law's implementation, as equity lies outside the law but seeks justice under certain conditions and circumstances.85 The existence of equity itself does not intend to alter or reduce justice, but rather provides corrections and/or complements in certain individual circumstances, conditions and specific cases. In other words, equity imposes the value of justice in inter-individual relationship with the objective of returning the parties to a reasonable position.86 In his book "Maxims of Equity", Francis has tried to formulate the guideline for equity, including:

a. Equity looks on as done that which ought to be done;

b. Equity follows the law;

c. He or she who comes into equity must come with clean hands;

d. He or she who seeks equity must do equity;

e. Equity does not allow a statute to be made an instrument of fraud;

f. Equality is equity;

g. Equity acts in personam; 
h. Equity will not assist a volunteer;

i. Equity look to intent not form;

j. Equity will not suffer a wrong to be without a remedy;

k. Where the equities are equal, the law prevails;

I. Where the equities are equal, the first in time prevails;

m. Equity aids the diligent not the tardy. 87

In a civil law system like in Indonesia, the principles of equity are manifested in the principle of good faith, appropriateness and correctness. One form of the principles of equity in Indonesian law can be observed in Article 1339 BW which states that "Agreements are not only binding for things expressly stated therein, but also for everything that is by nature of the agreement, required by appropriateness (billijkheid), customs or laws". In addition, the principle of equity is also reflected in the legal provisions on unlawful acts, namely by extending the scope of unlawful acts based on the Decision of Hoge Raad dated January 31, 1919 which extends the criteria of unlawful acts, which include acts contrary to the appropriateness which should be considered in the social interaction.88 Meanwhile, what is meant by the principle of equity in unjust enrichment has not been explicitly regulated in Indonesia.

In addition, factually to date within its Civil Code, Indonesia still does not have specific regulation on the act of unjust enrichment. Some scholars argue that the concept of unjust enrichment has been accommodated in the Law of Obligation, particularly in Article 1359 paragraph (1) of BW on unpaid payments which states that "each payment considers the presence of a debt; and what has been paid with no obligation can be reclaimed". Referring to this clause, there are several elements that can be observed, namely 1 ) the presence of payment; 2 ) the payment is based on the assumption from the paying party that he/she has a debt; 3 ) in fact the debt is absent; and 4) payments made may be reclaimed.

These elements indicate as if the payments are always in the form of money or material. However, as stated previously, the scope of unjust enrichment doctrine is not limited to objects of money, but also goods, even an achievement which brings out the right of claim for recovery of compensation for benefit.89 In addition, the provision of Article 1359 paragraph (1) of the BW also seems to limit that the indebted payment is made not only based on the existence of mistakes of fact alone, with the assumption that the paying party has a debt, but in fact not. This obviously greatly narrows the criterion of unjust enrichment which can also be based on the existence of mistakes of law, duress and many other factors. Thus it can be seen that the provisions of Article 1359 paragraph (1) BW cannot be compared as the complete concept of unjust enrichment, but only as a fraction of the scope of unjust enrichment concept.

Even if we make an analogy to the provisions of NBW, Article 1359 paragraph (1) of BW can only be analogized as performance not due as referred to in Article 203 up to Article 211 of Book 6 NBW. Furthermore NBW has established regulation on unjust enrichment in a separate sub-chapters, namely Article 212 Book 6 NBW. Therefore, it is necessary to regulate the basic application of unjust enrichment doctrine independently in, especially, Indonesian legislation, with the objective of providing the basis for the losing party to file restitution claims against his property in the event that there is no contractual relationship between the injured party and the gaining party or that there is no error or negligence from the gaining party, to manifest justice for the parties.

The value of justice and morals contained in the unjust enrichment doctrine itself is the need to provide legal protection for someone whose rights are unjustly reduced. In this case, despite having the unjust enrichment doctrine not optimally accommodated in positive law in Indonesia, the doctrine does contain both morals and justice, and there is a principle underlying the doctrine that can be applicable as law in Indonesia. It is in accordance with the objective of corrective justice which seeks to correct any injustice in a relationship between one party and another, indicated by the loss or disadvantage on the one party which due to the gain on the other party that is obtained improperly or obtained without the existence of a drawback (unjust enrichment), so that the losing or the disadvantaged party can claim restitution for his/her loss or disadvantage.90 


\section{CONCLUSION}

The gain and the loss in unjust enrichment are defined as a system of mutual reciprocity, in the sense that a loss on one hand shall be followed by a profit on the other hand. Unlike the concept of loss and gain in contractual relationships and related to unlawful acts, the gain and loss criteria in unjust enrichment are more than just mathematically calculated values. Rather, normatively the concept of gain and loss refers to the distinction between what the parties let go and what they must have in accordance with the norms governing the interaction or obligation between them. In other words, the loss and gain alone cannot indicate the presence of unjust enrichment, but to express the loss and gain in the unjust enrichment, the actions that cause the loss and the benefits on one party must meet the criteria of unjust enrichment. So the basis for determining profitability (and losses) is normatively the relevant legal norms that regulate the unjust enrichment criteria itself.

Corrective justice as the philosophical foundation of the regulations on unjust enrichment seeks to eliminate the unjustified gain that causes the loss on the other side, so that corrective justice seeks to provide restitution to the injured party or in other words to return the injured party to its original state prior to the loss. So the criteria to determine an unjust enrichment should be adjusted to the objective of justice that is manifested in the corrective justice.

\section{Suggestions}

1. It is necessary to reformulate the basic criteria of the default (or breach of contract) lawsuit and the unlawful acts which are still conventionally the basis of a lawsuit against the unjust enrichment doctrine. The repositioning of unjust enrichment doctrine in Indonesia is conducted to move from it from Criminal Code to Civil Code.

2. In achieving corrective justice, the unjust enrichment doctrine shall be incorporated in court decisions by re-establishing the basic principle of separation between the lawsuit for default and lawsuit for unlawful acts.

3. The incorporation of the unjust enrichment doctrine may also be the basis of changes in the national legal system for contracting, especially the law of obligation in Indonesia as the basis for the filing of restitution lawsuit in Indonesia.

\section{REFERENCES}

[1] Abdulkadir Muhammad, Hukum Perikatan, Alumni, Bandung, 1982.

[2] Agus Yudha Hernoko, Hukum Perjanjian Asas Proporsionalitas dalam Kontrak Komersial, LaksBang Mediatama Yogyakarta, Yogyakarta, 2008.

[3] Alvin W. L., "An Introduction to the Law of Unjust Enrichment", Malayan Law Journal,

Research Collection School of Law, 2013, http://ink.library.smu.edu.sg/sol_research/12 28.

[4 ]Alvon Kurnia Palma, et.al., Implementasi dan Pengaturan Illicit Enrichment (Peningkatan Kekayaan Secara Tidak Sah) di Indonesia, Indonesia Corruption Watch, Jakarta, 2014 http://www.antikorupsi.org/sites/antikorupsi. org/files/doc/Kajian/policypaperillicitenri chment.pdf.

[5] Andre Ata Ujan, Keadilan dan Demokrasi (Telaah Filsafat Politik John Rawls), Kanisius, Yogyakarta, 1999.

[6] Andrew Wallis \& Melanie Maslem, "The Scope and Operation of the Duty of Good Faith and Reasonableness", Australian Construction Newsletter, 79 Agustus/ September 2001, Pricewaterhouse Coopers Legal, http://www.austlii.edu.au/cgibin/sinodisp/au/journals/AUConstrLawNIr/20 01/58.html?stem=0\&synonyms=0\&quer $\mathrm{y}=$ good\%20faith\%20and\%20contractual\%20ju stice.

[7] Anton F. Susanto, "Keraguan dan Ketidakadilan Hukum (Sebuah Pembacaan Dekonstrukstif)", Jurnal Keadilan Sosial, First Ed. 2010.

[8] Aristoteles, Nicomachean Ethic, v.4.1131b251132b20, extracted from Ingram Bywater, ed., 1894.

[9] Burhanuddin Salam, Etika Sosial, Rineka Cipta, Jakarta, 1997.

[10] Dennis Klimchuck, Unjust Enrichment and Corrective Justice, dalam Jason W. Neyers, et.al., Understanding Unjust Enrichment, Hart Publishing, Ontario, 2004 
[11] E. Sumaryono, Etika Hukum Relevansi Teori Hukum Kodrat Thomas Aquinas, Kanisius, Yogyakarta, 2002.

[12] Eddy Neumann, Equity and Trust-Unjust Enrichment, FindLaw Australia, http://www.findlaw.com.au/articles/2163/eq uity-and-trusts-8211-unjust-enrichment.aspx.

[13] Ernest J. Weinrib, "Correlativity and Personality", dalam Corrective Justice, Oxford Legal Philosophy, Oxford, 2012.

[14] Ernest J. Weinrib, "Unjust Enrichment", Corrective Justice, Oxford Legal Philosopy, Vol. Januari 2013, http://oxfordindex.oup.com/view/10.1093/ac prof:oso/9780199660643.003.0007.

[15] Ernest J. Weinrib, The Gains and Losses of Corrective Justice, Essay http://scholarship.law.duke.edu/cgi/viewcont ent.cgi?article $=3264 \&$ context $=\mathrm{dlj}$.

[16] Ernest J. Weinrib, The Idea of Private Law, Harvard University Press, Cambridge, 1995.

[17] Frank Edgar, Narcissus and Echo, Greek and Roman Mythology, Mark Twin Media, United States of America, 1994, http://www.jcchs.org/Portals/0/Uploads/Unit $\% 2010 . p d f$

[18] Hans Warendorf, et.al., The Code Civil of the Netherland, Kluwer Law International, Netherlands, 2009.

[19] Henry Campbell, Black's Law dictionary, St. Paul Minn., West Publishing Co., 1990 Indonesia Corruption Watch, Miskinkan Koruptor Lewat Aturan "Illicit Enrichment",

[20] Indonesia Corruption Watch, http://www.antikorupsi.org/en/content/miski nkan-koruptor-lewat-aturan-illicitenrichment.

[21] James Penner, et.al., ed., Introduction to Jurisprudence and Legal Theory (Commentary and Materials), Butterworths, London, 2002.

[22] John Rawls, A Theory of Justice, Massachusetts: The Belknap Press of Havard University Press, Cambridge, 1971.

[23] Jules Coleman, "Corrective Justice and Wrongful Gain", Journal of Legal Studies, Vol. 11, 1982.

[24] Jules Coleman, "The Practice of Corrective Justice", Owen 1995.

[25] Jules Coleman, "Tort Law and the Demands of Corrective Justice", Indiana Law Review, Vol. 67, 1992.

[26] Julio Alberto Diaz, "Unjust Enrichment and Roman Law", Pensar, Fortaleza, 2007 http://www.ucc.ie/law/restitution/archive/ar ticles/diaz.pdf.

[27] K. Barker, "Unjust enrichment: Containing the Beast" 15 OJLS 457, 1995.

[28] L.B. Curzon, Equity, MacDonald \& Evans, London, 1967.

[29] L.J. van Apeldoorn, Pengantar Ilmu Hukum, Pradya Paramita, Jakarta, 2004.

[30] Lionel D. Smith, The Province of The Law of Restitution, 71 Canadian B. Rev. 672, 694-99 1992.

[31] Lord Lloyd of Hampstead \& M.D.A. Freeman, Lyoyd's Introduction to Jurisprudence, English Languange Book Society (ELBS), London, 1985.

[32] Marek Sobczyk, "Application of the Concept of Conditio Causa Data Causa Non Secuta in

Pecuniarym Settlements Between Cohabitants", Comparative Law Riview, Nicolaus Copernicus University, 2014, http://apcz.pl/czasopisma/index.php/CLR/arti cle/download/CLR.2014.010/5755.

[33] Maurice J. Holland, "Law of Restitution, by George E. Palmer", Indiana Law Journal, Vol. 54: Iss. 2, Article 6, http://www.repository.law.indiana.edu/ilj/vol 54/iss2/6.

[34] Nigel E. Simmonds, Central Issues in Jursprudence, Sweet \& Maxwell, London. O. Notohamidjojo, Masalah: Keadilan, Tirta Amerta, Semarang, 1971.

[35] Patrick Parkinson, The Principles of Equity, Lawbook, Sydney, 2003.

[36] Paul Vout, Principles of Private Law, The Melbourne JD, Trismester 2, 2005.

[37] Peter Birks, An Introduction to the Law of Restitution, Claredon Press, Oxford, 1985.

[38] Peter Birks, Unjust Enrichment, OUP, Oxford, 2005.

[39] Peter Mahmud Marzuki, Pengantar IImu Hukum, Kencana Prenada Media Group, Jakarta, 2009.

[40] Raymond Wacks, Jurisprudence, Blackstone Press Limited, London, 1995

[41] Renske Verhoeff, De Plaats van de verbintenis uit ongerechtvaardigde verrijking, volwaardig of subsidiair?, http://media.leidenuniv.nl/legacy/1011081renske-verhoeff-ba3scriptie.pdf.

[42] Richard A. Epstein, "Causation and Corrective Justice. A Reply to Two Critics", Journal of Legal Studies, Vol. 8. 
[43] Richard Stone, Principles of Contractual Law, Cavendish Publishing Limited, London, 2000

[44] Rosa Agustina, et al., Hukum Perikatan (Law of obligations), Pustaka Larasan, Denpasar,2012.

[45] Sarah Worthington, Equity, Oxford University Press, New York, 2003

[46] Scott Hershovitz, "Corrective Justice for Civil Recourse Theorists", Florida State Law Review, Vol. 39.

[47] Trevor C. Harley, International Commercial Litigation (Text, Cases and Materials on Private International Law, Cambridge University Press, New York, 2010

[48] Tulalip Shores, Inc., Respondent v. Elizabeth M. Mortland, et.al., Appellants, Division One. Court of Appeals No. 1361-1, 9 Juli 1973 http://courts.mrsc.org/mc/courts/zappellate/ 009wnapp/009wnapp0271.htm.

[49] Yahya Harahap, Hukum Acara Perdata, tentang Gugatan, Persidangan, Penyitaan, Pembuktian dan Putusan Pengadilan, Sinar Grafika, Jakarta, 2005. 